\title{
反射高速陽電子回折による表面研究
}

\author{
河裾 厚男・一宮 彪彦* \\ 日本原子力研究所高崎研究所 俨370-1292 群馬県高崎市綿貫町 1233 \\ *名古屋大学大学院工学研究科 - 464-8603 愛知県名古屋市千種区不老町
}

(2002 年 8 月 28 日受理)

\section{Surface Study Using Reflection High-energy Positron Diffraction}

Atsuo KawASUSO and Ayahiko ICHIMIYA*

Japan Atomic Energy Research Institute, Takasaki Establishment, 1233 Watanuki, Takasaki, Gunma 370-1292

${ }^{*}$ Faculty of Engineering, Nagoya University, Furo-cho, Chikusa-ku, Nagoya, Aichi 464-8603

(Received August 28, 2002)

\begin{abstract}
Reflection high-energy positron diffraction (RHEPD) is a new surface analysis tool having a capability to determine structure of adsorbed layers, surface Debye temperatures and metal dipole barriers with less disturbance from bulk. We have constructed a positron beam apparatus for RHEPD experiments and succeeded in observing RHEPD patterns and total reflection of positrons. In this article, we introduce the principle of RHEPD and some of its applications.
\end{abstract}

\section{1. は じめに}

ここで述べる反射高速陽電子回折 (RHEPD, Reflection High-Energy Positron Diffraction の略) とは, 電子の反粒 子である陽電子を用いる表面回折手法である。陽電子の 質量やスピンなどは電子と同一であるが, 電子とは反対 のプラス電荷を持つことから, 結晶表面による回折現象 にも電子との違いが現れると考えられていた"1)。その最 大の特徵は, 陽電子が最表面でのみ反射される “全反射 効果” の出現にある。全反射条件下では, 回折強度は最 表面構造を敏感に反映し, したがって電子回折では難し い最表面の構造解析を行うことができる。1998 年, 我々 は $20 \mathrm{keV}$ のエネルギーを持つ高速陽電子が結晶表面で 回折する現象を発見した ${ }^{2)}$ 。現在我々は, RHEPDを利 用して $\mathrm{Si}$ や $\mathrm{SiC}$ 半導体清浄表面の構造解析を行ってい る。本報では, RHEPD 法の原理とともにいくつかの応 用例について述べる。

\section{RHEPD の原理 ${ }^{1)}$ と装置開発}

一般に, 回折に対するブラッグ条件は次の式で与えら
れる。

$$
E \sin ^{2} \theta=37.5 n^{2} / d^{2}+V_{0}
$$
ここで, $E$ は入射粒子のエネルギー, $\theta$ は入射視射角, $d$ は格子面間隔, $n$ は整数, そして $V_{0}$ は結晶ポテンシ ヤルである。X 線に対しては, $V_{0}$ はゼロとなる。電子 の場合は $V_{0}<0$ となり, 逆に陽電子に対しては $V_{0}>0$ と なる。この陽電子と電子に対する結晶ポテンシャルの正 負の違いがそれぞれの回折現象に決定的な違いをもたら す。 $\mathrm{Si}$ (111) 面を例にとると, 電子回折に対しては（1） 式の右辺が負值（後述するように電子に対する Si の内 部ポテンシャルはー $12 \mathrm{eV}$ 程度である）となり, $n=1$ の 最低次ブラッグ反射は出てこない。一方, 陽電子の場合 には（1）式の右辺は常に正值となり最低次ブラッグ反 射が観測される。さらに, 入射エネルギーの表面垂直方 向成分 $\left(E_{\perp}\right)$ が $V_{0}$ よりも小さい, 即ち,

$$
E_{\perp}=E \sin ^{2} \theta<V_{0}
$$

の場合（これは（1）式において $n=0$ の条件となる） には, 陽電子は試料内部に進入することなく最表面で全 反射される。内部ポテンシャルについては, 古くは Bethe ${ }^{3)}$ が以下の式で与えている。

$$
V_{0}=-\frac{3}{10} \frac{e^{2} p}{4 \pi \varepsilon_{0} r_{0}}
$$


ここで, $p$ は自由電子数, $r_{0}$ は原子容積から得られる半 径である。一方, Doyle と Turner ${ }^{4)}$ の電子散乱因子から 内部ポテンシャルを見積もることができる。それによれ ば, $\mathrm{Si}$ の陽電子に対する内部ポテンシャルは $V_{0}=+12$ $\mathrm{eV}$ となる。そこで, 式 (2) から $E=20 \mathrm{keV}$ の場合の 全反射臨界角は $\theta_{\mathrm{c}}=1.4^{\circ}$ となる。実際, 一宮のマルチス ライス法を用いる動力学計算 ${ }^{5}$ を行うと Fig. 1 に示すよ うなロッキング曲線が得られる。入射視射角が $1.4^{\circ}$ 以下 のところで回折強度が高くなっているのが全反射の効果 である。ここで, 本来全反射であれば, 回折強度は（反 射率=) $100 \%$ となり角度に依らず一定となるが，実際 には幾何因子 $(\sin \theta)$ が乗ぜられることになり， $\theta=0^{\circ}$ から $1.4^{\circ}$ で増加傾向となる。また $1.6^{\circ}$ 付近に最低次のブ ラッグ反射が現れることがわかる。同図に示す RHEED の場合には二次以上のブラッグ反射しか現れないことと 比較すると, これらは顕著な違いであることがわかる。 全反射効果は, $X$ 線回折や陽子線散乱でも現れることが 知られている。これらと比べると，RHEPDの全反射は 比較的高角度で起こり実験が容易になる。

以上は理想的に平坦な表面についてであるが，最表面 に吸着原子などが存在すると状況はさらに一変する。

Fig. 2 に示すように, 全反射領域では陽電子は吸着原子 で回折されるとともに，吸着層をトンネル効果によって 透過し基板結晶表面でも回折される。これら 2 つ回折

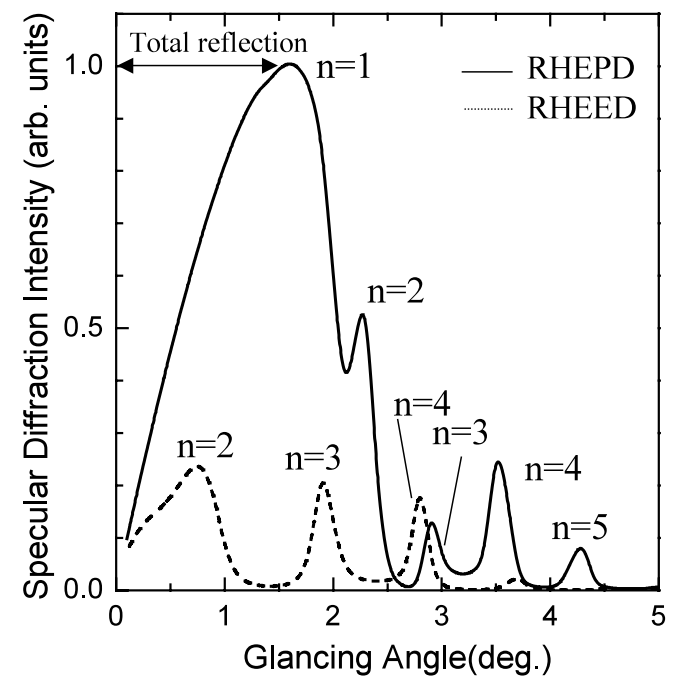

Fig. 1 Rocking curves of bulk-truncated Si(111) surface for reflection high-energy positron diffraction (RHEPD) and reflection high-energy electron diffraction (RHEED) obtained by Ichimiya's dynamical calculation method. Incident positron and electron energy is $20 \mathrm{keV}$.
線の間で干渉効果が引き起こされ，全反射強度曲線に吸 収ピーク（ディップ）をもたらす。全反射領域では，陽 電子回折強度は内部の影響を殆ど受けないので, 回折強 度の温度依存性を調べることで, 表面デバイ温度をバル クの影響なく決定できると考えられる。金属表面付近で は, 自由電子が真空領域にし夕出し, 電気二重層を形成 していると考えられている。これは，ダイポール障壁と して仕事関数の成因となるものであるが，直接測定する 方法が確立されていない。RHEPD 全反射強度測定はダ イポール障壁の決定にも利用できると考えられてい る6)。このように, RHEPD 法を用いることで, 最表面 の原子構造や電子状態についての知見を得ることができ る。

陽電子は, $\beta^{+}$崩壊する放射性同位元素によって得る ことができる。放射性同位元素から放出される陽電子は, 幅の広いエネルギースペクトルを持っており，そのまま ではビームとして利用することができない。そこで，夕 ングステン箔を減速材とすることでエネルギーの良く揃 つた低速陽電子を得るという方法がとられる。低速陽電 子を静電的に加速することで任意のエネルギーの陽電子 ビームを形成することができる。Fig. 3 は，我々がこれ まで試作した RHEPD 装置の概略である。線源としては

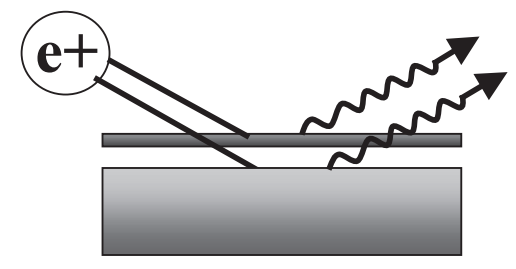

Double potential for $\mathrm{e}^{+}$

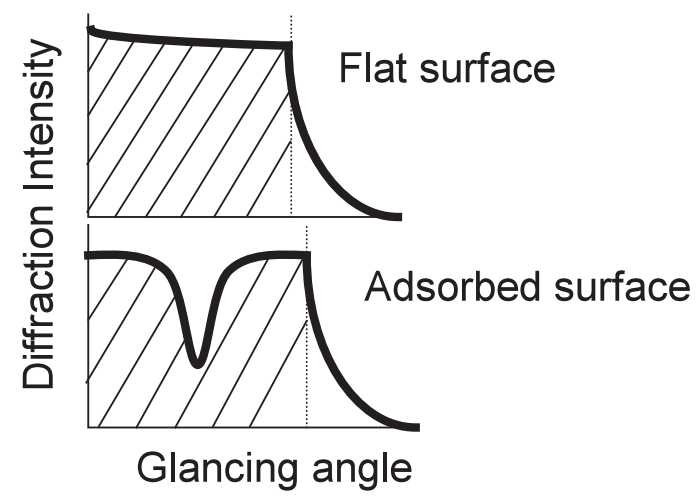

Fig. 2 Schematic representation of positron reflection at topmost surface through a double potential and its effect on RHEPD rocking curve. 


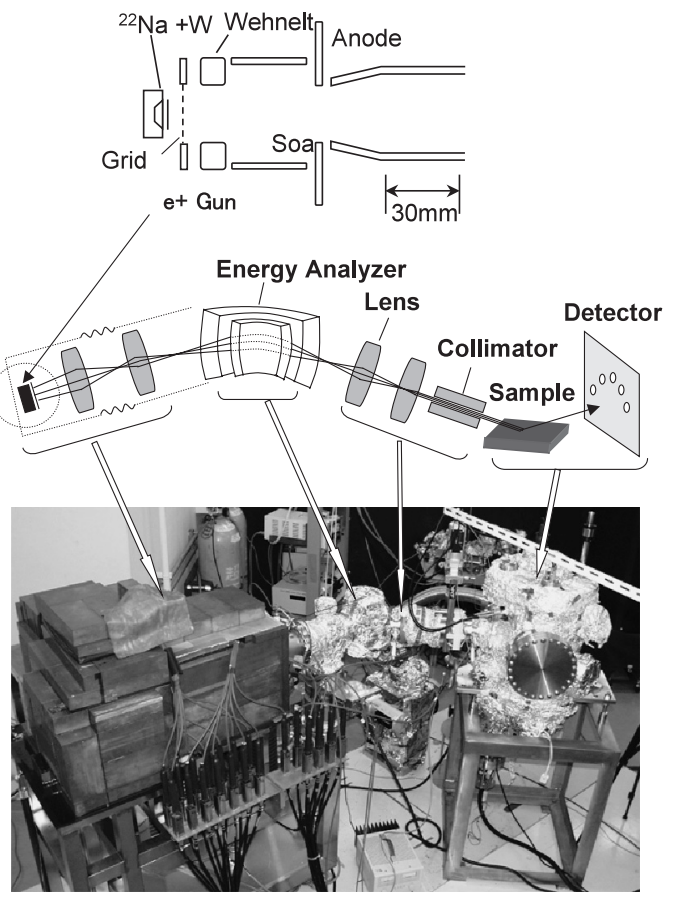

Fig. 3 RHEPD apparatus developed by authors.

$370 \mathrm{MBq}$ の ${ }^{22} \mathrm{Na}$ を使用している。低速陽電子発生部は, 引き出し電極, ウェネルト電極, ソア管, およびアノー ド電極から構成されている。この方法は, 改良型ソア銃 と呼ばれ米国ブランダイス大学の Canter ら゙が低速陽電 子回折を行った際に使用したものとほぼ同型である。陽 電子ビームの加速は静電界によって行い, ビーム集束は アインツェルレンズを使用している。また, ビームエネ ルギー分散の低減のために, 同心円球状のエネルギーア ナライザーを設置している。回折実験には小径（直径 1 $\mathrm{mm}$ 以下）かつ高平行（角度分散 0.1 度以下）のビーム が必要となる。線源として点状のものを使用することが できれば，比較的簡単に小径・高平行ビームを得ること ができる。しかし, 現在の線源は直径 $5 \mathrm{~mm}$ であるので, 平行性を保ちつつビーム径を絞るのは原理的に不可能で ある。一方，一度得られた陽電子ビームをもう一度減速 材に投入してビームの小径化を図る “輝度増強技術” が 提案されているが, これでは装置が複雑になる上にビー 厶強度の低下を免れないという弱点がある。そこで, 我々 は中心軸上のビームのみをピンホールコリメータで切り 出す方法によって小径・高平行ビームを形成することと した。陽電子フラックスは毎秒 $2 \times 10^{3}$ 程度と微弱であ る。そこで, 蛍光板付マイクロチャンネルプレートを用 いて回折ビームを検出し, CCD カメラによって得た画

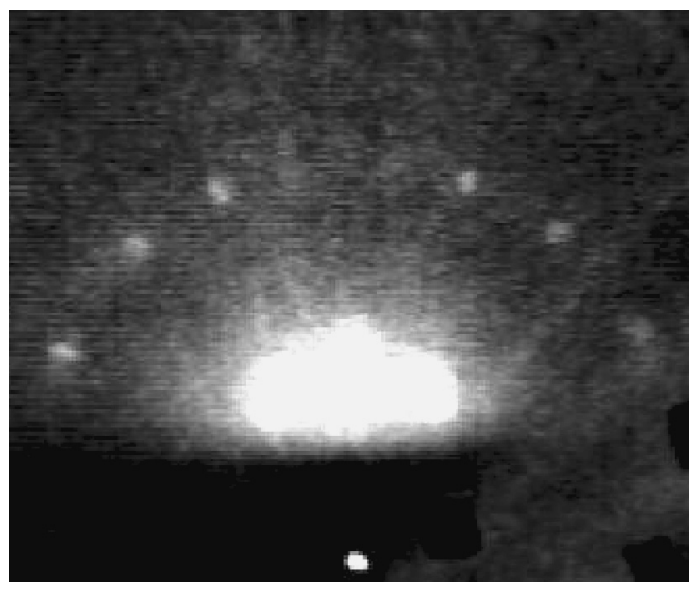

Fig. 4 RHEPD pattern obtained from a hydrogen-terminated $\mathrm{Si}(111)$ surface with a positron beam of which energy is $20 \mathrm{keV}$. Incident direction is [112] and glancing angle is $4^{\circ}$.

像をパソコンでデジタルデータとして蓄積することで, 回折図形や回折強度を得るような仕組みを構成した。

当初は上述した装置においてエネルギーアナライザー は設置しておらず，ゼロ次ラウエ帯のみが観測されてい た。その後の装置改良の結果, 現在では Fig. 4 に示すよ うに一次ラウエ帯を含む回折図形を観測することができ るようになった ${ }^{8)}$ 。Fig. 5 はエネルギー $20 \mathrm{keV}$ の陽電子 ビームを用いて得た水素終端 $\mathrm{Si}$ (111) 表面に対する鏡 面反射点強度の角度依存性（ロッキング曲線）である。 比較のため $10 \mathrm{keV}$ 電子線を用いる RHEED 実験で得ら れたロッキング曲線を示す。RHEED では一次ブラッグ 反射が誘起されない。またこの場合は三次以上のブラッ グ反射のみが見える。これとは対照的に，RHEPDでは 相対強度の強い一次ブラッグ反射が明暸に観測される 他, 低角度領域には全反射に起因する強度分布が観測さ れる (解析については次節で述べる)。回折パターン自 体は, 表面原子配列の周期性を反映するため, RHEPD と RHEED では大きな違いは見られないが，上の結果は ロッキング曲線に大きな違いがあることを示している。 一宮が動力学理論に基づき予測した効果が, 実験的に確 認されたといえる。表面敏感な全反射や一次ブラッグ反 射が実際に観測できたことは重要である。より定量的に 表面構造を評価するためには，以下で述べるように表面 原子配列モデルをもとに理論計算を行い実験と比較する 必要がある。

\section{3. 水素終端した $\mathrm{Si}(111)$ 表面の構造解析 ${ }^{91}$}

Si の水素終端処理によって, 吸着に対して不活性で 


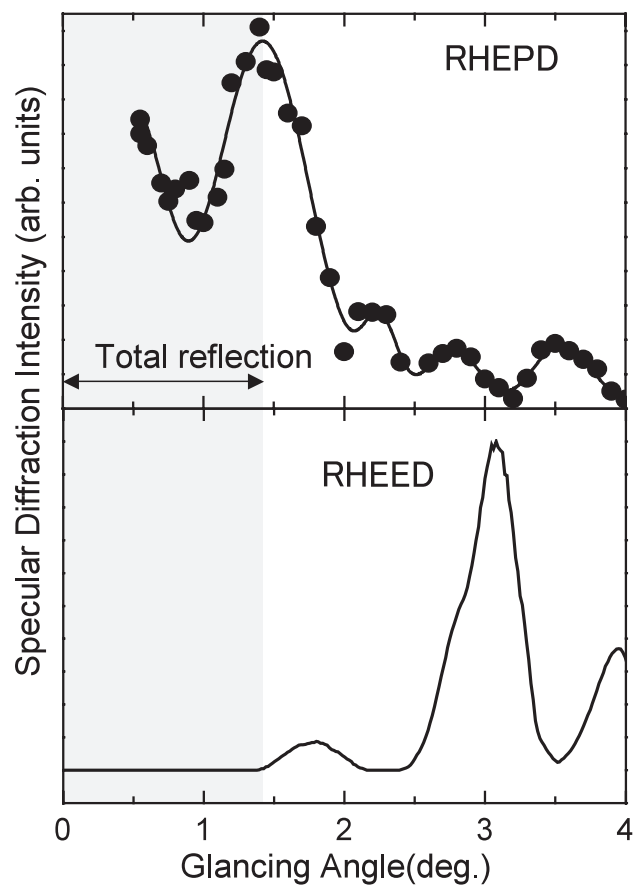

Fig. 5 RHEPD and RHEED rocking curves obtained from a hydrogen-terminated $\mathrm{Si}(111)$ surface at [112] incidence. Positron energy is $20 \mathrm{keV}$. Electron energy is $10 \mathrm{keV}$.

高い原子平坦性を持つ表面を得ることができる。これは 工業的に重用であり, これまで多くの精力的な研究が進 められてきた。初期の研究では, 水素雾囲気中で試料を アニールすることによって水素終端面を得るという方法 （ドライ）がとられたが, 現在では化学的な方法（ウェ ット）が主流である。市販の $\mathrm{Si}$ 基板には, 保護膜とし て薄い酸化膜が形成されている。これを希釈したフッ酸 （HF）溶液につけることで, 酸化膜が除去され表面に現 れたダングリングボンドが水素原子によって終端され る。より平坦な水素終端面を得るためには, さらに濃硝 酸 $\left(\mathrm{HNO}_{3}\right)$ 中で試料を煮沸することで表面を犠牲酸化 し,これをフッ酸により除去するという工程を繰り返し, 最終的にフッ化アンモニウム $\left(\mathrm{NH}_{4} \mathrm{~F}\right)$ や䋧衝フッ酸溶 液により仕上げるという方法がとられる。このようにし て得られた $\mathrm{Si}$ 表面は, 原子的に平坦でかつ単一水素 （三Si-H，モノハイドライド）で覆われていると考えられ ている。実際 Fig. 6 に示すように, フッ化アンモニウム で最終仕上げを行った水素終端表面からは，モノハイド ライドの伸縮振動に起因する赤外吸収ピークが観測され る。また, 原子間力顕微鏡によって得られる表面粗さは広 い範囲にわたって 1 Å程度であることも確かめられた。

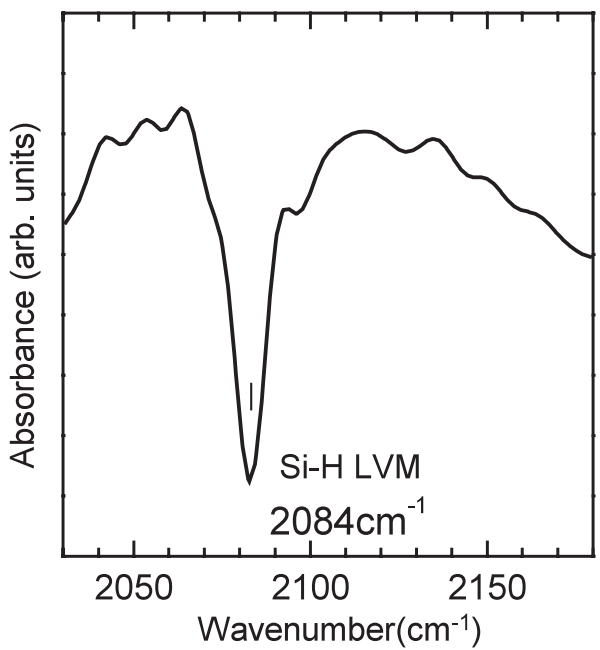

Fig. 6 Infrared absorption spectrum obtained from a hydrogen-terminated $\mathrm{Si}(111)$ surface.

水素終端した $\mathrm{Si}$ (111) 表面に対する鏡面反射点の口 ッキング曲線は Fig. 5 のようになる。ここで，全反射領 域には特徵的なディップ構造が見られることがわかる。 このような振る舞いは, 既に Fig. 1 に示したように, 完 全平坦面に対しては期待することができない。即ち, Fig. 2 に模式的に示すように表面には二重障壁があって，陽 電子波がそれぞれの障壁で回折され，これら 2 つの波の 間で干渉が生じて強度の落ち込みがもたらされると考え られる。この二重障壁の成因としては吸着や表面ラフネ スの効果が考えられる。ここで, 表面のダングリングボ ンドが水素原子で終端されているが，水素原子による原 子散乱因子は $\mathrm{Si}$ 原子のそれと比べて十分に小さいので, 回折に与える効果はほとんど無視できる。そこで，表面 ラフネスによる効果を考えることにする。原子間力顕微 鏡の結果から，ラフネスが存在するとしても，それは一 原子面間隔程度のものと考えられる。そこで, Fig. 7 に 示すように (a) Missing Top Layer, (b) Bilayer Roughness, および (c) Missing Top Layer \& Roughness といったモデ ルを仮定して動力学的計算によりロッキング曲線を求め た。ただし，格子面間隔等はバルク結晶と同じ值とした。 ただし，(b) における最表面の=SiH および（c）におけ る- $\mathrm{SiH}_{3}$ の表面被覆率は, それぞれ 0.4 および 0.2 とした。 何れのモデルにおいても, 全反射領域に吸収ピークが現 れることがわかる。このうち, 吸収ピーク位置と曲線形 状から Missing Top Layer \& Roughness モデルが最も実験 結果を良く再現していることがわかる。

以上のように水素終端した $\mathrm{Si}$ (111）表面には原子レ 


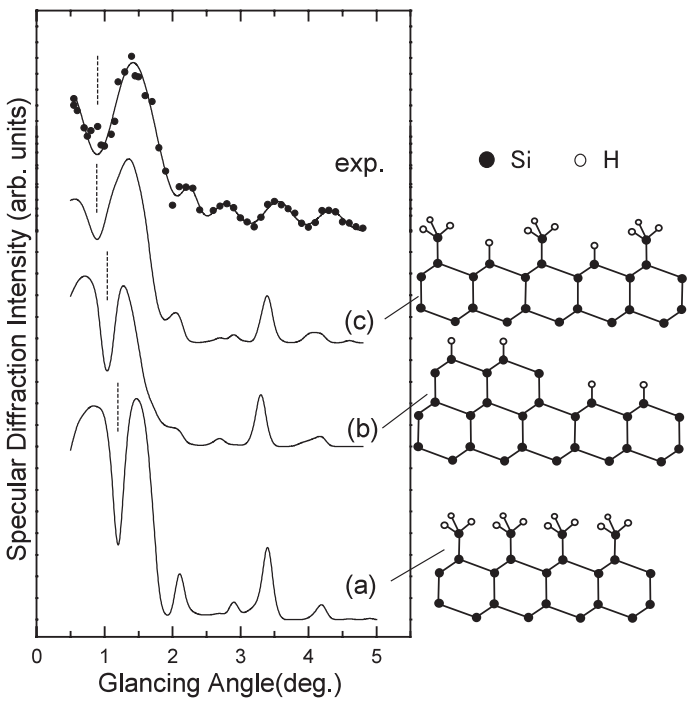

Fig. 7 Calculated RHEPD rocking curves based on the following models (a) Missing Top Layer, (b) Bilayer Roughness, and (c) Missing Top Layer \& Roughness. Bond length is fixed at that for an ideal crystal, e.g., $2.35 \AA$ for $\mathrm{Si}-\mathrm{Si}$.

ベルで見て一層程度のラフネスがあって，それがモノハ イドライド (三Si-H) で覆われた面にトリハイドライド $\left(-\mathrm{SiH}_{3}\right)$ が分布しているような構造であることが示唆さ れる。実際ウェット法で作製した $\mathrm{Si}$ (111) 水素終端面 にトリハイドライドが存在するという報告は，STMや 光電子分光の研究によってなされていた。ここで述べた RHEPD による観測結果は，そのような報告を裏付ける ものである。

\section{4. $\mathrm{SiC}(0001)$ 表面の構造解析}

$\mathrm{SiC}$ は次世代の耐環境デバイス材料として，近年その 研究開発が進められている。ホモエピ層の形成や酸化膜 界面特性の制御之関連して, 表面解析は特に重要な課題 である。SiCには多形現象があり，閃亜鉛構造の立方晶 だけでなく，様々な積層周期を持つ六方晶が存在する。 バンドギャップの大きな六方晶 $\mathrm{SiC}$ は $\mathrm{c}$ 軸方向に優先的 に成長するので, 通常 (0001) 面が得られる。理想(0001) 面は $\mathrm{Si}$ 原子によって終端されており, その反対の (0001) 面は C 原子で終端されている。

切出されたままの $\mathrm{SiC}$ 表面には, 研磨傷などの荒れが 多数存在している。実際のデバイス作製時には，これら を除去し平滑な表面を得る必要がある。一般に $\mathrm{KOH}$ 溶液による機械化学研磨法がとられる。しかしながら,

Fig. 8 (a) にAFM 像を示すように現在市販されている $\mathrm{SiC}$ (0001) 表面は非常に荒れていることが問題となって

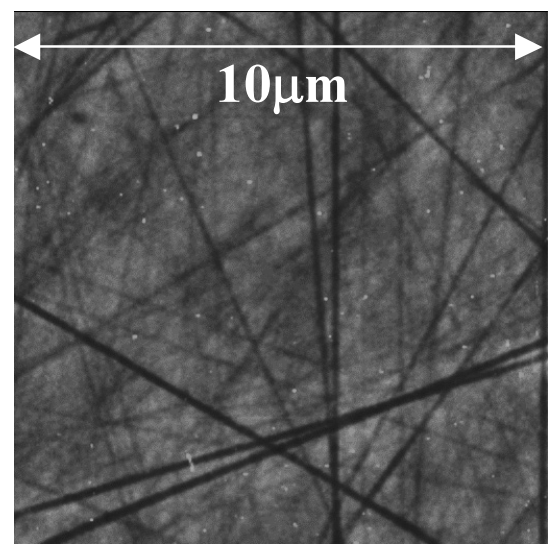

(a)As-received

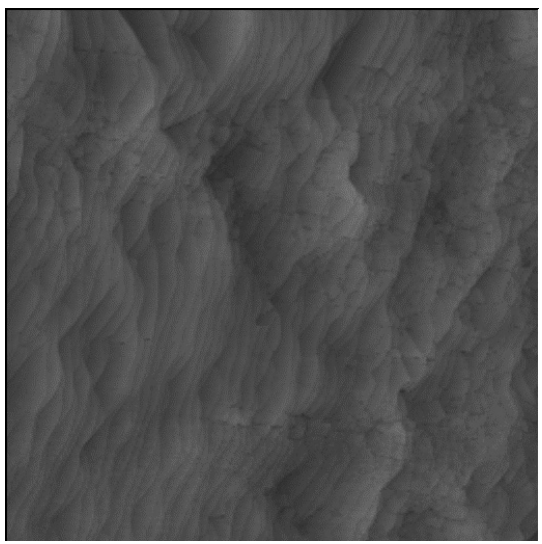

(b) $\mathrm{H}_{2}$ annealed

Fig. 8 Atomic force microscopy images from $\mathrm{SiC}(0001)$ surfaces (a) in as-received state and (b) after high temperature hydrogen annealing at $1450{ }^{\circ} \mathrm{C}$.

いる。高温水素ガスアニール ${ }^{10}$ は有効な表面平滑化法の 1つである。そこで， $6 \mathrm{H} \mathrm{SiC}(0001)$ 表面に対して，温 度 $1450^{\circ} \mathrm{C}$ ，水素ガス圧 100 Torr，流量 $2 \mathrm{slm}$ ，および時 間 8 時間の条件下で水素ガスアニールを行ったところ, 実際 Fig. 8 (b) に示すように表面研磨傷が除去されて, 平坦なテラスが出現することがわかった。なお，本処理 は CVD 結晶成長炉を用いて行った。詳細な解析からテ ラスの間隔は $100 \mathrm{~nm}$ 程度であった。また，隣接するテ ラス間のステップ高さは $2 \AA$ 程度, ステップ内の平均ラ フネスは 1 Å以下であった。一方，Fig.9に示すように, オージェ電子分光による表面組成分析の結果，表面には 酸素が吸着していることが確認された。酸素吸着の原因 はまだ明らかでないが，高温水素ガスアニール後の大気 開放時，またはアニール炉内の残留酸素ガスによるもの 


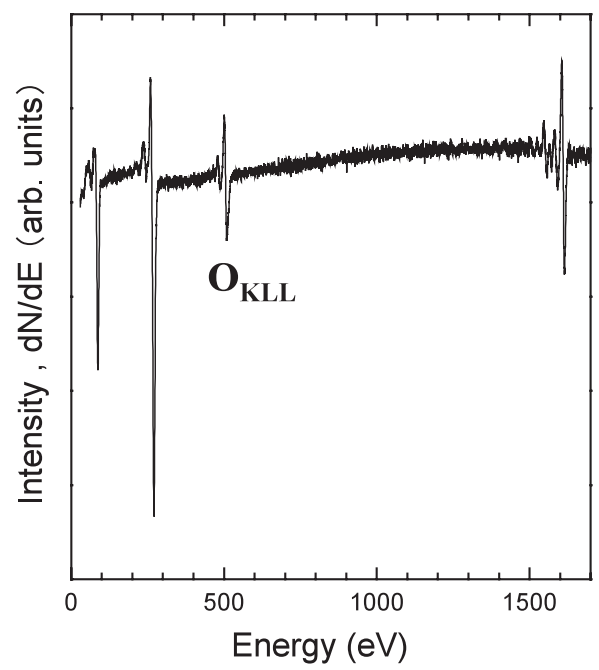

Fig. 9 Auger electron spectrum from $\mathrm{SiC}(0001)$ surface after high temperature hydrogen annealing at $1450{ }^{\circ} \mathrm{C}$.

と考えられる。このように, 高温水素ガスアニールした $\mathrm{SiC}$ 表面は原子的に平坦であるが，表面には酸素吸着層 が形成される ${ }^{11}$ 。

本試料に対して陽電子回折図形は $1 \times 1$ 構造を示して いた。一方，鏡面反射点のロッキング曲線は Fig. 10 (a) に示すようになる。回折強度は $0.5-1.2^{\circ}$ で一定值をとっ た後増加し, 約 $1.7^{\circ}$ 付近にピークを示すとともに, $2.5^{\circ}$ $(n=2), 3.4^{\circ}(n=3), 4.2^{\circ} \quad(n=4)$ のように高次ブラッ グ反射が出現する。全反射領域 $\left(\theta<1.6^{\circ}\right)$ の回折強度 分布は，平坦 $\mathrm{SiC}$ 表面として説明することはできない。 上でも述べたように酸素吸着効果を考虑する必要があ る。そこで, より詳しく酸素吸着効果を調べるために, 酸素原子を積極的に吸着させた状態についても同様の実 験を行った。ここでは, 試料を $1200^{\circ} \mathrm{C}$ の乾燥酸素ガス 中で 4 時間酸化した後，HFによるエッチングを行った。 このような処理では, 表面に酸素が残留することが知ら れている。Fig. 10（b）に示すように，この処理条件で は $\theta=1.2^{\circ}$ 付近に明らかな吸収ピーク（ディップ）が現 れる。これは，上でも述べたように表面二重障壁が形成 されたことによる干渉効果として説明できる。Fig. 10 (a) の高温水素ガスアニールの場合でも同様のことが考えら れるが，明確な吸収ピークとならないのは，二重障壁の 成因となる吸着子の被覆率が相対的に低いためと考えら れる。低エネルギー電子回折の実験において, 酸素の吸 着位置は Fig. 11 に示すように $T_{1}$ サイト ( $\mathrm{Si}$ 原子の直上) と考えられている"1)。そこで，試みに本モデルに基づき 動力学計算を行った。Si-O の結合長は約 1.7-1.8 ゙̊̊あ り，酸素の表面被覆率は (a)，(b) それぞれについて 0.2

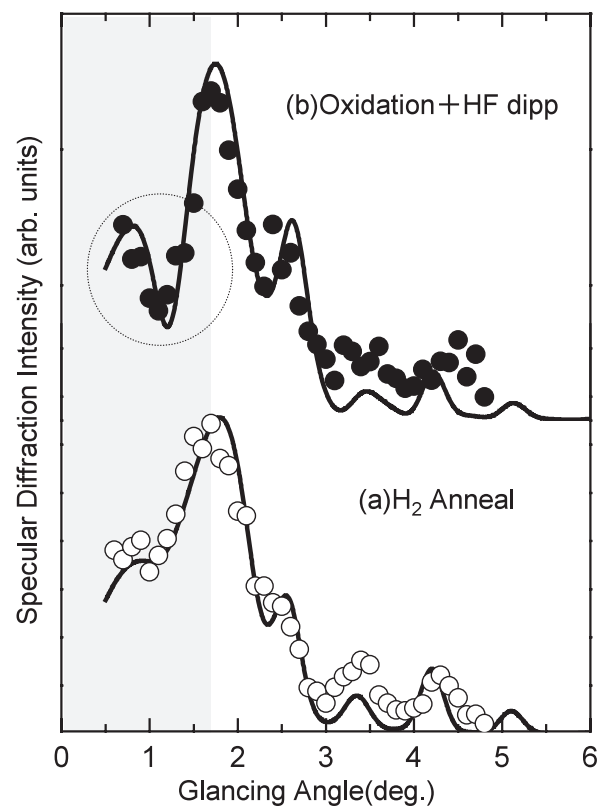

Fig. 10 RHEPD rocking curves obtained from $\mathrm{SiC}(0001)$ surfaces (a) after high temperature hydrogen annealing at $1450^{\circ} \mathrm{C}$ and (b) after sacrificial oxidation at $1200^{\circ} \mathrm{C}$ for $4 \mathrm{~h}$ in a dry oxygen ambient and subsequent dipping into $\mathrm{HF}(50 \%)$ solution.
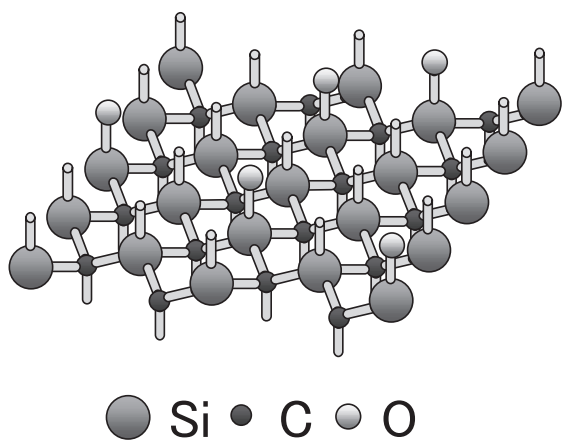

Fig. 11 Schematic view of oxygen adsorbed $\mathrm{SiC}(0001)$ surface.

と 0.5 とした。また, その他の結合長はバルク結晶の值 とした。図中の実線は計算の結果を示している。何れの 場合も，得られた実験結果が良く再現できることがわか る。また Si-O の結合長は，低エネルギー電子回折の実 験で得られている $1.67 \AA$ と比較的良く一致している。低 速電子回折と同様にフィッティングの良さを示す Pendry の R 因子を求めたところ，(a)，(b) 何れの場合も 0.1 程度となり，低エネルギー電子回折の值（0.15-0.2）を 下回っていた。ここで電子回折と比較して重要なことは, 
フィッティングパラメータが著しく低減できること，そ して得られた最表面に関する構造が内部の構造にあまり 大きく影響されないことである。

以上より, 高温水素ガスアニールおよび酸化膜の $\mathrm{HF}$ による除去によって仕上げられた $\mathrm{SiC}(0001)$ 表面には 酸素原子が吸着しており, その結果 RHEPD 全反射領域 に量子力学的な干渉効果に起因する吸収ピークが出現す ることが明らかになった。 $\mathrm{SiC}(0001)$ 表面に吸着した酸 素原子は超高真空中における $900^{\circ} \mathrm{C}$ 以上の熱処理によ って除去され, その後超構造が形成されると考えられて いる。また, 酸素吸着効果は (0001) および (1120) や（1100）等の面方位では異なるとされている。今後, これらについても研究を進めてゆく必要があると考えら れる。

\section{5. と め}

反射高速陽電子回折（RHEPD）の原理, 開発, そし て表面構造解析における応用例について述べた。高速陽 電子の表面全反射現象が確かめられたとともに, 全反射 強度分布が最表面原子構造に敏感であることがわかっ た。近接場法に代表される顕微鏡法では, 表面原子の二 次元配列はわかっても深さ方向の情報を得ることは難し いし, 観測の対象が限定される。また, 電子回折では表 面再構成に付随する周期性は良くわかるが, 回折強度分 布には最表面だけでなくバルクの影響が含まれる。
RHEPD を複合的に用いることで，これらの長所を活か し短所を補うことができる。今後, RHEPDによる各種 の表面吸着構造や表面デバイ温度そして金属表面障壁の 研究の展開を目指したい。

\section{文献}

1) A. Ichimiya: Solid State Phenomena 28/29, 143 (1992, 1993).

2) A. Kawasuso and S. Okada: Phys. Rev. Lett. 81, 2695 (1998).

3) H.A. Bethe: Ann. Phys. 87, 55 (1928).

4) P.A. Doyle and P.S. Turner: Acta Cryst. A 24, 390 (1968).

5) A. Ichimiya: Jpn. J. Appl. Phys. 22, 176 (1983).

6) J. Oliva: $\mathrm{Ph}$. D. thesis, University of California at San Diego (1979, unpublished).

7) K.F. Canter, P.H. Lippel, W.S. Crane and A.P. Mills, Jr.: "Positron Studies of Solids, Surfaces, and Atoms" (World Scientific, Singapore, 1986) p. 199.

8) A. Kawasuso, T. Ishimoto, S. Okada, H. Itoh and A. Ichimiya: Appl. Surf. Sci. 194, 287 (2002).

9) A. Kawasuso, M. Yoshikawa, K. Kojima, S. Okada and A. Ichimiya: Phys. Rev. B 61, 2102 (2000).

10) P. Mårtensson, F. Owman and L.I. Johansson: Phys. Stat. Sol. (b) 202, 501 (1997).

11) U. Starke: Phys. Stat. Sol. (b) 202, 475 (1997). 